\title{
Examining lung cancer risks across different industries and occupations in Ontario, Canada: the establishment of the Occupational Disease Surveillance System
}

\author{
James K H Jung, ${ }^{1,2}$ Saul G Feinstein, ${ }^{1}$ Luis Palma Lazgare, ${ }^{1}$ Jill S Macleod, ${ }^{1}$ \\ Victoria H Arrandale, ${ }^{1,2}$ Christopher B McLeod, ${ }^{3}$ Alice Peter, ${ }^{4}$ Paul A Demers ${ }^{1,2,3}$
}

- Additional material is published online only. To view, please visit the journal online (http://dx.doi.org/10.1136/ oemed-2017-104926).

${ }^{1}$ Occupational Cancer Research Centre, Cancer Care Ontario, Toronto, Ontario, Canada 2Dalla Lana School of Public Health, University of Toronto, Toronto, Ontario, Canada ${ }^{3}$ School of Population and Public Health, University of British Columbia, Vancouver, British Columbia, Canada

${ }^{4}$ Population Health and Prevention, Cancer Care Ontario, Toronto, Ontario, Canada

\section{Correspondence to}

Dr Paul A Demers, Occupational Cancer Research Centre, Cancer Care Ontario, Toronto, ON M5G 2L3, Canada;

Paul.Demers@cancercare.on.ca

Received 30 November 2017 Revised 28 March 2018 Accepted 19 April 2018 Published Online First 7 May 2018

\section{Linked}

- http://dx.doi.org/10.1136/ oemed-2018-105189

\section{Check for updates}

To cite: Jung JKH, Feinstein SG, Palma Lazgare L, et al. Occup Environ Med 2018:75:545-552.

\section{ABSTRACT}

Background The Occupational Disease Surveillance System (ODSS) was established in Ontario, Canada by linking a cohort of workers with data created from Workplace Safety and Insurance Board (WSIB) claims to administrative health databases. The aim of this study was to use ODSS to identify high-risk industry and occupation groups for lung cancer in Ontario. Methods Workers in the WSIB lost time claims database were linked to the Ontario Cancer Registry using subjects' health insurance numbers, name, sex, birthdate and death date (if applicable). Several occupations and industries known to be at increased risk were outlined a priori to examine whether ODSS could replicate these associations. Age-adjusted, sex-stratified Cox proportional hazard models compared the risk of lung cancer within one industry/occupation versus all other groups in the cohort. Workers with a lung cancer diagnosis prior to cohort entry were excluded for analysis, leaving 2187762 workers for analysis.

Results During the 1983 to 2014 follow-up, 34661 workers in the cohort were diagnosed with lung cancer. Among expected high-risk industries, elevated risks were observed among workers in quarries/sand pits and construction industries for both sexes, and among males in metal mines, iron foundries, non-metallic mineral products industries and transportation industries. Excess risk was also observed among occupations in drilling/ blasting, other mining/quarrying, mineral ore treating, excavating/grading/paving, truck driving, painting, bus driving and construction.

Conclusions This current surveillance system identified several established high-risk groups for lung cancer and could be used for ongoing surveillance of occupational lung cancer in Ontario.

\section{INTRODUCTION}

In Canada, lung cancer is fourth in cancer incidence for men and third in women and is the leading cause of cancer mortality in males and females. ${ }^{1}$ Although lung cancer incidence is no longer increasing in Canada, the 5-year survival rate remains low $(17 \%){ }^{1}$ As lung cancer is primarily caused by smoking, prevention efforts have largely focused on tobacco control. However, while approximately $15 \%$ of lung cancer cases have been attributed to occupational exposures, ${ }^{2}$ such hazards have

\section{Key messages}

What is already known about this subject?

- About $15 \%$ of lung cancer cases can be attributed to workplace exposures, and a number of occupations are exposed to known carcinogens such as asbestos, silica dust and diesel engine exhaust.

What are the new findings?

- The Occupational Disease Surveillance System (ODSS) confirmed many well-established highrisk groups for lung cancer such as those in construction, mining and transportation.

- Other high-risk groups included workers in industries of defence services and occupations such as metal forging workers, janitors/ charworkers/cleaners and motor vehicle fabricating/assembling positions.

How might this impact on policy or clinical practice in the foreseeable future?

- ODSS can provide quantitative risk estimates for occupational diseases at a population level that are necessary to support the targeting of workrelated disease prevention programmes.

typically not been a priority in cancer prevention policies. ${ }^{3} \mathrm{~A}$ focus on lung cancer prevention beyond smoking could further reduce future incidence. ${ }^{4}$

The International Agency for Research on Cancer (IARC) has identified many occupational exposures such as asbestos, silica dust, chromium VI compounds, diesel engine exhaust, nickel, paint and welding fumes as lung carcinogens with sufficient evidence in humans. ${ }^{5}$ As such, there is strong evidence linking excess lung cancer risk to employment in occupations including construction ${ }^{6}$; quarries, sand pits and mining $^{7}$; transportation $^{89}$; painting ${ }^{10}$ and welding, ${ }^{11}$ even after adjusting for smoking.

As ongoing monitoring is needed for disease prevention, some attempts have been made to establish surveillance systems for occupational cancers. Internationally, the best models have been based on large-scale record linkages. An example is the Nordic Occupational Cancer (NOCCA) surveillance system, ${ }^{12}$ where occupational information from 
five Nordic countries (Denmark, Finland, Iceland, Norway and Sweden) was obtained through census data, which was then linked to national cancer registries. However, census linkages are only possible in a small number of countries where complete occupational information is collected in linkable form. In North America, the surveillance of occupational cancers has largely been based on cause-specific mortality patterns by occupation and industry using death certificate records. ${ }^{13}$ However, this form of surveillance can be limited by the lack of accuracy in recording occupational information (ie, they reflect the most recent occupation at time of death and not at time of exposure). Moreover, death records cannot be used to study non-fatal cancers.

In Canada, the existence of a single payer health system and the maintenance of comprehensive administrative health databases helps facilitate health surveillance for the population. Yet despite the availability of high-quality information on new disease diagnoses, the initiation of occupational disease surveillance continues to be limited by the absence of information on occupation and industry of employment in the administrative health data. Koehoorn et $a l^{14}$ addressed this limitation by identifying industry of employment using data from the provincial health registry for British Columbia, Canada, which identify the name of employers for people whose premiums are employer paid. This database was linked to administrative health data to explore high-risk industries for asthma. Cherry et $a l^{15}$ used an alternative approach to overcome this challenge by linking workers' compensation claims-which contained data on occupation and industry of employment at the time of injury or illness resulting in the claim-to physician billing records for asthma in Alberta, Canada. Using unique personal health numbers to match the claims to the provincial administrative health database, occupations with higher than expected rates of asthma were identified.

These linkage approaches created an avenue of performing occupational disease surveillance that could be used as a model for other jurisdictions. The Occupational Disease Surveillance System (ODSS) was developed in the province of Ontario, Canada to link workers' information on occupation and industry (based on workers' compensation claims) to administrative health databases. While ODSS was developed for the surveillance of a variety of occupational diseases, the first focus was to examine occupational cancers through a linkage to the provincial cancer registry. Specifically, lung cancer was the first occupational disease examined using ODSS as it is one of the most common occupational cancers with a well-established set of occupational risk factors. ${ }^{16}$

The objective of this study was to use ODSS to identify highrisk industry and occupation groups for lung cancer in Ontario, Canada. We first examined the effectiveness of ODSS in identifying known high-risk groups for lung cancer, which could provide support for this project as an ongoing surveillance system for occupational disease. Additionally, ODSS was used to investigate other suspected occupational associations for lung cancer, which could serve as a basis for future research.

\section{METHODS}

The ODSS was established through the linkage of a cohort of workers created with data from Ontario Workplace Safety and Insurance Board (WSIB) claims with administrative health databases (see figure 1). The system acts as a prospective open occupational cohort since additional workers can enter the cohort through new WSIB claims over time. This study obtained ethics approval from the University of Toronto Health Sciences Research Ethics Board.

\section{Creation of the ODSS cohort}

The WSIB claims database includes all accepted lost time claims (applications submitted when employees suffer a work-related injury or disease that can lead to permanent disability and/or loss of wages) by workers in Ontario, providing the occupation and industry data from 1983 to 2014. Claims preceding 1983 were more likely to have missing data for key linkage variables and were excluded. The database includes: occupation/ industry code (specific to employment related to the compensation claim), claim date, the nature of work-related injuries and/or illnesses, worker's name, sex, birthdate and death date (if applicable). In this database, industry was coded according to the Canadian Standard Industry Classification 1970 (SIC-70) and 1980 (SIC-80) codes. For analytical purposes, all industry codes were converted to SIC-70, where industries could be classified by division, ${ }^{10}$ major (49) or minor (248) groups. Occupations were coded according to the Canadian Classification Dictionary of Occupation (CCDO) at the 4-digit level. Using these codes, occupations could be classified by division, ${ }^{17}$ major (88) or minor (487) groups.

An internal linkage of the WSIB claims database was completed to link multiple claims records belonging to the same worker using the AutoMatch V.4.2 (MatchWare Technologies, Inc., Silver Spring, Maryland, USA) probabilistic record linkage software. This application was used to group multiple records for a single worker within a file and generate a unique identifier. Of 3833772 WSIB claims between 1983 and 2014, we identified 2253734 unique workers.

\section{Exclusion criteria}

Workers were excluded due to:

- Missing sex

- Missing/invalid birthdate

- Age at claim under 15 years old

- Invalid claim date

- Missing/invalid both the SIC-70 and CCDO codes.

This resulted in 2190246 unique workers included as the ODSS worker cohort.

\section{Linkage with administrative health data}

Workers from the WSIB claims database were linked to the Registered Persons Database (RPDB; 1991-2015). This database contains information for individuals who are registered for insured health services in the province through the Ontario Health Insurance Plan (OHIP). The RPDB contains information on sex, residence location, birthdate, death date (if applicable), date of emigration from province (if applicable) and health insurance number (HIN). Information on name, sex, birthdate and death date was used to link workers from the WSIB claims database ( $n=2253$ 734) with the RPDB ( $n=16162$ 277).

OHIP-registered persons are assigned a unique 10-digit HIN, and this identifier can be used to match individuals to other administrative health databases. Using a combination of the identifying information listed above, approximately $82 \%$ of all workers in the ODSS cohort (1 796731 unique subjects) were linked to HINs.

\section{Ontario Cancer Registry (OCR)}

The OCR maintained by Cancer Care Ontario ( $\mathrm{n}=2050$ 907) ${ }^{18}$ contains information on incident cancer cases in Ontario (19642016), excluding non-melanoma skin cancers. The registry collects data from several sources including hospital discharge and day surgery records, pathology reports from hospital and 


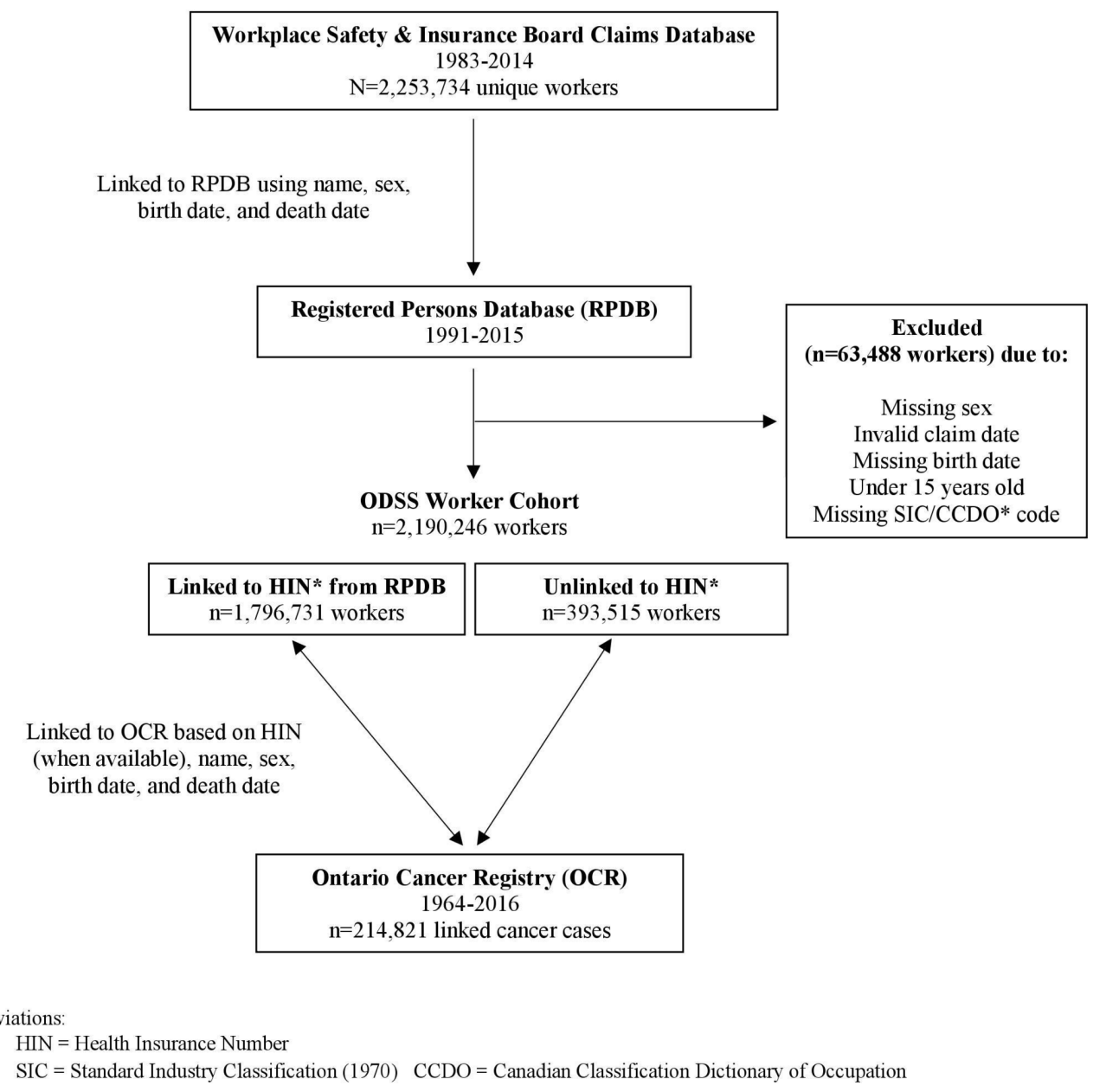

Figure 1 Establishing the ODSS worker cohort through the linkage of administrative health databases. ODSS, Occupational Disease Surveillance System.

community laboratories, records from regional cancer centres and death certificates received from the Registrar General. Incident cancers were coded according to the International Classification of Disease 10 th edition. ${ }^{19}$

Following the linkage to the RPDB, the workers were linked to the OCR deterministically using the subjects' HIN, if available. Where no HIN was available, the linkage was probabilistic, using name, sex, birthdate and death date. In total, 214821 unique workers in the ODSS cohort with at least one cancer diagnosis were linked to the OCR. Only the first tumour at the primary site (malignant cases only) was considered.

\section{Statistical analysis}

For cohort members, the date of entry into the cohort was the date of their first accepted lost time WSIB compensation claim. Follow-up continued until cancer diagnosis, year of death, emigration out of province or administrative censoring (31 December 2016), whichever occurred first. Workers with a lung cancer diagnosis prior to cohort entry were excluded from the analysis (leaving 2187762 workers for analysis). Disease risk was estimated with Cox proportional hazard models using a rolling cohort analysis, where the risk of cancers within one industry or occupation group was compared with the rest of the cohort. ${ }^{8}$ HRs and 99\% CIs were calculated for each occupation and industry group, adjusted for year of birth. Sex-stratified analyses were also conducted. Results were reported for only the groups that met the reporting threshold of at least six cases. All analyses were completed using SAS V.9.4 (SAS Institute).

\section{A priori selection of groups for analyses}

Known associations between workplace exposures and lung cancer risks were identified a priori. These served as a guideline to examine whether ODSS could accurately identify established high-risk groups and demonstrate its utility as a valid surveillance tool. The senior author (PAD), an occupational epidemiologist with expertise in industrial hygiene, performed the selection of the groups. Groups with known occupational exposures to carcinogens classified by IARC as Group 1 (sufficient evidence in humans) were identified as a priori groups. Other groups of interest included those with suspected increased risk due to occupational exposures, based on evidence from scientific literature and/or expert knowledge. In total, 37 industries and 49 occupations were preidentified for this analysis, selected from the major and minor levels. Additionally, the results for all industries and occupations at the division level were provided.

\section{RESULTS}

Among the 2187762 ODSS cohort workers (66\% males, $\mathrm{n}=1440683$ ), 34661 workers with lung cancer were identified during the 1983 to 2014 follow-up. The mean age at cohort entry was 37.4 years (SD 12.3). Table 1 provides the risk estimates for all industries and occupations at the division level. Tables 2 and 3 provide the risk estimates for the a priori groups and other suspected groups of interest, and table 4 summarises the a priori groups that showed positive associations for lung cancer as expected. The results for all industry and occupation 
Table 1 HRs for lung cancer among all industries and occupations, division level

\begin{tabular}{|c|c|c|}
\hline Industry/occupation & $\begin{array}{l}\text { Cases } \\
\text { (no of workers) }\end{array}$ & $\begin{array}{l}\text { HR } \\
(99 \% \mathrm{Cl})\end{array}$ \\
\hline \multicolumn{3}{|l|}{ Industry } \\
\hline Agriculture & 379 (35 120) & 0.81 (0.71 to 0.92$)$ \\
\hline Forestry, fishing and trapping & $249(10721)$ & 1.15 (0.97 to 1.35$)$ \\
\hline $\begin{array}{l}\text { Mines (including milling), } \\
\text { quarries and oil wells }\end{array}$ & 798 (23 204) & 1.43 (1.30 to 1.57$)$ \\
\hline Manufacturing & $12692(694723)$ & 0.98 (0.95 to 1.01$)$ \\
\hline Construction & 3648 (211 549) & 1.09 (1.04 to 1.14$)$ \\
\hline $\begin{array}{l}\text { Transportation, communication } \\
\text { and other utilities }\end{array}$ & 3533 (197 529) & 1.14 (1.09 to 1.19$)$ \\
\hline Wholesale and retail trade & 5396 (429 870) & 0.99 (0.95 to 1.03$)$ \\
\hline $\begin{array}{l}\text { Finance, insurance and real } \\
\text { estate }\end{array}$ & $479(24020)$ & 1.15 (1.02 to 1.30$)$ \\
\hline $\begin{array}{l}\text { Community, business and } \\
\text { personal service }\end{array}$ & 7266 (600 256) & 0.95 (0.92 to 0.99$)$ \\
\hline $\begin{array}{l}\text { Public administration and } \\
\text { defence }\end{array}$ & 3311 (191 092) & 1.04 (1.00 to 1.09$)$ \\
\hline \multicolumn{3}{|l|}{ Occupation } \\
\hline $\begin{array}{l}\text { Managerial, administrative and } \\
\text { related }\end{array}$ & $347(31028)$ & 1.03 (0.90 to 1.18$)$ \\
\hline $\begin{array}{l}\text { Natural sciences, engineering } \\
\text { and mathematics }\end{array}$ & $287(26366)$ & 0.85 (0.73 to 0.99$)$ \\
\hline $\begin{array}{l}\text { Social sciences and related } \\
\text { fields }\end{array}$ & $250(30721)$ & 1.04 (0.88 to 1.22$)$ \\
\hline Teaching and related & 335 (48 506) & 0.61 (0.53 to 0.71$)$ \\
\hline Medicine/health & 1462 (135 434) & 0.85 (0.79 to 0.91$)$ \\
\hline $\begin{array}{l}\text { Artistic, literary, recreational } \\
\text { and related }\end{array}$ & $131(15003)$ & 1.11 (0.88 to 1.39$)$ \\
\hline Clerical and related & 2824 (197 515) & 1.09 (1.04 to 1.15$)$ \\
\hline Sales & 1515 (148 237) & 1.06 (0.99 to 1.14$)$ \\
\hline Service & 5389 (371 247) & 1.06 (1.01 to 1.10$)$ \\
\hline $\begin{array}{l}\text { Farming, horticultural and } \\
\text { animal husbandry }\end{array}$ & $555(50265)$ & 0.88 (0.79 to 0.98$)$ \\
\hline $\begin{array}{l}\text { Fishing, hunting, trapping and } \\
\text { related occupations }\end{array}$ & $11(558)$ & 1.16 (0.53 to 2.52$)$ \\
\hline Forestry/logging & $216(10707)$ & 1.04 (0.87 to 1.24$)$ \\
\hline $\begin{array}{l}\text { Mining/quarrying including oil/ } \\
\text { gas field }\end{array}$ & $441(13034)$ & 1.47 (1.29 to 1.66$)$ \\
\hline $\begin{array}{l}\text { Processing—metal/clay, glass, } \\
\text { stone/chemicals }\end{array}$ & 1427 (79 369) & 1.18 (1.10 to 1.26$)$ \\
\hline $\begin{array}{l}\text { Processing—food/wood/pulp/ } \\
\text { textile }\end{array}$ & 1428 (99 358) & 1.00 (0.93 to 1.07$)$ \\
\hline Machining and related & 3615 (189 751) & 1.11 (1.06 to 1.16$)$ \\
\hline $\begin{array}{l}\text { Product fabricating, assembling } \\
\text { and repairing }\end{array}$ & $5816(328720)$ & 1.01 (0.98 to 1.05 ) \\
\hline Construction trades & 4076 (216 079) & 1.09 (1.05 to 1.14$)$ \\
\hline Transport equipment operating & 3672 (168 429) & 1.39 (1.33 to 1.46$)$ \\
\hline $\begin{array}{l}\text { Materials handling and related, } \\
\text { NEC }\end{array}$ & 2522 (153 276) & 1.11 (1.05 to 1.17$)$ \\
\hline $\begin{array}{l}\text { Other crafts and equipment } \\
\text { operating }\end{array}$ & $572(28350)$ & 1.12 (1.00 to 1.25$)$ \\
\hline Occupation NEC & 3410 (215 574) & 1.10 (1.05 to 1.16$)$ \\
\hline
\end{tabular}

NEC, not elsewhere classified.

groups, stratified by sex, can be found in online supplementary tables 1-6.

\section{Industry groups}

At the division level, the highest risks were observed in mining/quarries, transportation/communication/other utilities,
Table 2 HRs for lung cancer among a priori industry groups and other suspected industries of interest (at the major level unless otherwise noted)

\begin{tabular}{|c|c|c|}
\hline Industry & $\begin{array}{l}\text { Cases } \\
\text { (no of workers) }\end{array}$ & $\begin{array}{l}\text { HR } \\
(99 \% \mathrm{Cl})\end{array}$ \\
\hline \multicolumn{3}{|l|}{ A priori groups } \\
\hline Metal mines & $578(13859)$ & 1.46 (1.31 to 1.63$)$ \\
\hline Non-metal mines & 35 (1089) & 1.44 (0.93 to 2.22$)$ \\
\hline Quarries/sand pits & $110(4025)$ & 1.60 (1.25 to 2.05$)$ \\
\hline Rubber products* & $227(13041)$ & 0.97 (0.82 to 1.15$)$ \\
\hline Iron/steel mills* & $641(21695)$ & 1.07 (0.97 to 1.19$)$ \\
\hline Iron foundries* & $168(6168)$ & 1.28 (1.05 to 1.56$)$ \\
\hline Smelting/refining* & 38 (983) & 1.16 (0.77 to 1.77$)$ \\
\hline Shipbuilding/repair* & $24(907)$ & 1.05 (0.62 to 1.78$)$ \\
\hline Non-metallic mineral products & 585 (24 915) & 1.22 (1.10 to 1.36$)$ \\
\hline General contractors & $1448(74814)$ & 1.17 (1.09 to 1.25$)$ \\
\hline Special-trade contractors & 2367 (145 370) & 1.05 (0.99 to 1.11$)$ \\
\hline Transportation & $2523(136038)$ & 1.21 (1.15 to 1.28$)$ \\
\hline Blacksmithing/welding shops* & $71(3750)$ & 1.24 (0.91 to 1.68$)$ \\
\hline \multicolumn{3}{|l|}{ Other suspected groups of interest } \\
\hline Agriculture & $379(35120)$ & 0.81 (0.71 to 0.92 ) \\
\hline Forestry & $242(10300)$ & 1.15 (0.98 to 1.36$)$ \\
\hline Services incidental to mining & $87(4643)$ & 1.13 (0.86 to 1.49$)$ \\
\hline Tobacco products & $35(1117)$ & 1.27 (0.82 to 1.96$)$ \\
\hline Plastics fabricating* & $502(40883)$ & 0.91 (0.81 to 1.03 ) \\
\hline Leather & $79(5685)$ & 0.71 (0.53 to 0.95$)$ \\
\hline Textile & 369 (19 316) & 1.06 (0.93 to 1.21$)$ \\
\hline Wood & $542(38173)$ & 1.03 (0.92 to 1.15$)$ \\
\hline Furniture/fixture & $357(30257)$ & 0.69 (0.60 to 0.79$)$ \\
\hline Paper & $512(25284)$ & 1.03 (0.92 to 1.16$)$ \\
\hline Printing/publishing & 450 (25 996) & 1.13 (1.00 to 1.28$)$ \\
\hline Metal fabricating & $2038(127741)$ & 1.01 (0.95 to 1.07$)$ \\
\hline Machinery (except electrical) & 856 (41 851) & 1.04 (0.95 to 1.14$)$ \\
\hline Electrical products & $824(38553)$ & 1.08 (0.99 to 1.18$)$ \\
\hline Petroleum/coal products & $17(1$ 158) & 0.74 (0.40 to 1.38$)$ \\
\hline Chemical/chemical products & $357(21553)$ & 0.96 (0.84 to 1.10$)$ \\
\hline Paint/varnish manufacturers* & $37(2054)$ & 0.90 (0.59 to 1.38$)$ \\
\hline Storage & $136(10628)$ & 1.23 (0.98 to 1.53$)$ \\
\hline $\begin{array}{l}\text { Electric power, gas and water } \\
\text { utilities }\end{array}$ & $415(22415)$ & 1.03 (0.91 to 1.17$)$ \\
\hline Wholesale trade & 2036 (151 240) & 1.05 (0.99 to 1.11$)$ \\
\hline Motor vehicle repair shops* & 476 (36 454) & 1.05 (0.93 to 1.19$)$ \\
\hline Health/welfare services & 2381 (178 587) & 0.94 (0.89 to 0.99$)$ \\
\hline $\begin{array}{l}\text { Restaurants, caterers and } \\
\text { taverns* }\end{array}$ & 1042 (125 953) & 0.88 (0.81 to 0.96$)$ \\
\hline Defence services* & $187(5736)$ & 1.38 (1.14 to 1.66$)$ \\
\hline
\end{tabular}

*Minor industry group.

construction and finance/insurance/real estate industries. Agriculture was the only industry to show significantly reduced risks (table 1).

A priori industry groups that showed significantly increased risks included quarries/sand pits, metal mines, iron foundries, non-metallic mineral products, transportation and general contractors (table 2). Based on sex-stratified results, metal mines, non-metallic mineral products industries, transportation industries and general contractors reached significance only in males (although the first three still showed excess risk in females) (Supplementary file). Among male general contractors, highway/ bridge/street construction (HR 1.61, 99\% CI 1.39 to 1.87) and 
Table 3 HRs for lung cancer among a priori occupation groups and other suspected occupations of interest (at the major level unless otherwise noted)

\begin{tabular}{|c|c|c|}
\hline Occupation & $\begin{array}{l}\text { Cases } \\
\text { (no of workers) }\end{array}$ & $\begin{array}{l}\text { HR } \\
(99 \% \mathrm{Cl})\end{array}$ \\
\hline \multicolumn{3}{|l|}{ A priori groups } \\
\hline Bartenders* & $72(4431)$ & 1.62 (1.19 to 2.19$)$ \\
\hline Waiters, hostesses and stewards* & $321(32038)$ & 0.96 (0.83 to 1.11$)$ \\
\hline Drilling/blasting & $165(3482)$ & 1.61 (1.32 to 1.97$)$ \\
\hline $\begin{array}{l}\text { Other mining/quarrying including } \\
\text { oil/gas field }\end{array}$ & $333(10522)$ & 1.53 (1.33 to 1.76$)$ \\
\hline Mineral ore treating & $42(983)$ & 1.54 (1.04 to 2.29$)$ \\
\hline $\begin{array}{l}\text { Metal smelting, converting and } \\
\text { refining* }\end{array}$ & $70(2310)$ & 1.15 (0.84 to 1.56$)$ \\
\hline $\begin{array}{l}\text { Clay, glass and stone processing/ } \\
\text { forming }\end{array}$ & $255(10$ 187) & 1.24 (1.05 to 1.46$)$ \\
\hline Welding/flame cutting ${ }^{*}$ & $904(47110)$ & 1.08 (0.99 to 1.18 ) \\
\hline $\begin{array}{l}\text { Boilermakers, platers and } \\
\text { structural metal workers* }\end{array}$ & $98(4432)$ & 1.85 (1.43 to 2.40$)$ \\
\hline $\begin{array}{l}\text { Painting/decorating, except } \\
\text { construction* }\end{array}$ & $221(11466)$ & 1.25 (1.05 to 1.48$)$ \\
\hline Excavating/grading/paving & $536(18394)$ & 1.52 (1.36 to 1.70$)$ \\
\hline Construction trades & 3057 (165 414) & 1.09 (1.03 to 1.14$)$ \\
\hline Railway transport operating & $97(4033)$ & $1.23(0.95$ to 1.60$)$ \\
\hline Bus drivers* & 239 (7733) & 1.23 (1.04 to 1.46$)$ \\
\hline Truck drivers & $3011(122525)$ & 1.48 (1.41 to 1.56$)$ \\
\hline $\begin{array}{l}\text { Stationary engine/utilities } \\
\text { equipment operating }\end{array}$ & 207 (7596) & 1.24 (1.04 to 1.48$)$ \\
\hline \multicolumn{3}{|l|}{ Other suspected groups of interest } \\
\hline $\begin{array}{l}\text { Nursing therapy and related } \\
\text { assisting }\end{array}$ & 1369 (124 139) & 0.85 (0.79 to 0.91$)$ \\
\hline $\begin{array}{l}\text { Radiological technologists/ } \\
\text { technicians* }\end{array}$ & $10(1305)$ & 0.88 (0.39 to 1.99$)$ \\
\hline Firefighting & $174(12076)$ & 0.92 (0.76 to 1.12$)$ \\
\hline Police/detectives & $185(23360)$ & 0.67 (0.56 to 0.82$)$ \\
\hline Guards/watchmen* & $426(23879)$ & 1.29 (1.14 to 1.46$)$ \\
\hline Chefs/cooks* & $522(46128)$ & 0.98 (0.87 to 1.09$)$ \\
\hline $\begin{array}{l}\text { Barbers, hairdressers and } \\
\text { related }^{*}\end{array}$ & $12(1304)$ & 0.87 (0.41 to 1.82 ) \\
\hline Laundering/dry cleaning & $119(7115)$ & 1.02 (0.81 to 1.30$)$ \\
\hline Janitors/charworkers/cleaners & 2179 (103 022) & 1.25 (1.18 to 1.32$)$ \\
\hline Farmers/farm management & 45 (4389) & 0.69 (0.47 to 1.01$)$ \\
\hline Farm, nursery and related & $498(43787)$ & 0.92 (0.82 to 1.03$)$ \\
\hline Forestry/logging & $216(10707)$ & 1.04 (0.87 to 1.24$)$ \\
\hline $\begin{array}{l}\text { Chemicals, petroleum, rubber, } \\
\text { plastic processing }\end{array}$ & $556(41570)$ & 1.09 (0.97 to 1.21$)$ \\
\hline $\begin{array}{l}\text { Wood processing except paper } \\
\text { pulp }\end{array}$ & $113(6664)$ & 1.18 (0.92 to 1.50$)$ \\
\hline Pulp/papermaking and related & $100(5710)$ & $0.92(0.71$ to 1.19$)$ \\
\hline Textile processing & 169 (9782) & 1.11 (0.91 to 1.35$)$ \\
\hline Tobacco processing* & $11(433)$ & 1.11 (0.51 to 2.41$)$ \\
\hline Metal machining & $808(41797)$ & 1.07 (0.98 to 1.18$)$ \\
\hline Forging* & $63(2529)$ & 1.64 (1.19 to 2.27$)$ \\
\hline Wood machining & 105 (8749) & $0.87(0.67$ to 1.11$)$ \\
\hline Engravers, etchers and related* & $12(995)$ & 1.85 (0.88 to 3.89$)$ \\
\hline Patternmakers/mouldmakers* & $23(1537)$ & 1.31 (0.77 to 2.24$)$ \\
\hline F/A: motor vehicle* & $917(53476)$ & 1.19 (1.09 to 1.30$)$ \\
\hline F/A: electrical/related equipment & $673(38180)$ & 1.11 (1.00 to 1.22$)$ \\
\hline F/A: wood products & $304(24588)$ & 0.76 (0.65 to 0.88$)$ \\
\hline $\begin{array}{l}\text { F/A: textile, fur and leather } \\
\text { products }\end{array}$ & $417(26683)$ & 0.74 (0.65 to 0.84$)$ \\
\hline
\end{tabular}

\begin{tabular}{|c|c|c|}
\hline Occupation & $\begin{array}{l}\text { Cases } \\
\text { (no of workers) }\end{array}$ & $\begin{array}{l}\text { HR } \\
(99 \% \mathrm{Cl})\end{array}$ \\
\hline $\begin{array}{l}\text { F/A: rubber, plastic and related } \\
\text { products }\end{array}$ & 259 (15 244) & 0.92 (0.78 to 1.08 ) \\
\hline Motor vehicle mechanics* & 946 (59 343) & 1.02 (0.93 to 1.11$)$ \\
\hline Paper product F/A* & $129(6840)$ & 1.12 (0.89 to 1.40$)$ \\
\hline Water transport operating & $44(2694)$ & 0.98 (0.66 to 1.44$)$ \\
\hline Taxi drivers/chauffeurs ${ }^{\star}$ & 82 (3427) & 1.18 (0.89 to 1.57$)$ \\
\hline Printing press* & $140(7853)$ & 1.09 (0.88 to 1.36$)$ \\
\hline Bookbinders and related ${ }^{*}$ & 68 (3626) & 1.25 (0.91 to 1.71$)$ \\
\hline
\end{tabular}

*Minor occupation group.

F/A, fabricating/assembling.

other construction (HR 1.32, 99\% CI 1.13 to 1.55 ) showed significantly increased risks. Among males in the mining industries, employment in uranium mines (HR 1.93, 99\% CI 1.50 to 2.47) showed the highest risk. Although employment in asbestos mines showed significantly elevated risks, the number of total cases was below the reporting threshold.

Among other suspected industry groups of interest, the only industry that showed significantly increased risks was defence services.

\section{Occupation groups}

The division level results show that the highest risks were observed among occupations in mining/quarrying, transport equipment operating, metal/clay/glass/stone/chemicals processing, construction trades and machining (table 1). Teaching and medicine/ health occupations showed the lowest risks.

A priori occupation groups that showed significantly increased risks included boilermakers/platers/structural metal workers, drilling/blasting, mineral ore treating, other mining/quarrying, excavating/grading/paving, bartending, truck driving, painting/ decorating, stationary engine/utilities equipment operating, bus driving and construction. Based on sex-specific results, boilermakers/platers/structural metal workers reached significance only among males, bartenders and painting/decorating positions reached significance only in females and neither sex reached significance when stratified for mineral ore treating positions and bus drivers (Supplementary file). However, both sexes still showed excess risk in all of these groups. Among the construction trades, those with significantly increased risks included insulating occupations (HR 2.52, 99\% CI 1.71 to 3.71), painters/ paperhangers (HR 1.41, 99\% CI 1.18 to 1.69), structural metal erectors (HR 1.37, 99\% CI 1.05 to 1.79) and plasterers (HR $1.30,99 \%$ CI 1.03 to 1.65 ) for males. Although glaziers showed significantly elevated risks among females, the number of cases in these groups was below the reporting threshold.

Other occupations of interest with significantly elevated risks included metal forging workers, janitors/charworkers/cleaners and motor vehicle fabricating/assembling positions.

\section{DISCUSSION}

The ODSS identified positive associations for the majority of industries (12/13) and occupations (15/16) selected a priori to have an increased risk of lung cancer, although not all reached statistical significance. Pukkala and colleagues reported similar findings in their paper on the NOCCA surveillance system, ${ }^{12}$ which obtained occupational information from census data. Similar to ODSS, NOCCA observed significantly elevated risks for lung cancer among miners, quarry workers, construction 
Table 4 Summary of industry and occupation groups selected a priori expected to be at high risk

\begin{tabular}{|c|c|c|c|c|c|c|c|}
\hline \multirow[b]{2}{*}{ Industry/occupation } & \multirow[b]{2}{*}{ Exposure } & \multicolumn{2}{|l|}{ Overall } & \multicolumn{2}{|l|}{ Male } & \multicolumn{2}{|l|}{ Female } \\
\hline & & Association & Probability & Association & Probability & Association & Probability \\
\hline \multicolumn{8}{|l|}{ Industry } \\
\hline Metal mines & $\begin{array}{l}\text { Silica, asbestos, diesel } \\
\text { exhaust, nickel }\end{array}$ & + & ** & + & $* * *$ & ++ & . \\
\hline Non-metal mines & $\begin{array}{l}\text { Silica, asbestos, diesel } \\
\text { exhaust, radon }\end{array}$ & + & *** & + & * & $x$ & $x$ \\
\hline Quarries/sand pits & $\begin{array}{l}\text { Silica, asbestos, diesel } \\
\text { exhaust }\end{array}$ & ++ & $* * *$ & ++ & $* * *$ & $x$ & $\mathrm{x}$ \\
\hline Rubber products industries & $\begin{array}{l}\text { Dust/fumes/chemicals from } \\
\text { rubber production }\end{array}$ & Null & . & - & . & + & . \\
\hline Iron/steel mills & Silica, PAHs & + & ** & + & . & + & . \\
\hline Iron foundries & Silica, PAHs & + & $* * *$ & + & ** & $\mathrm{x}$ & $x$ \\
\hline Smelting/refining & Cadmium, arsenic, nickel & + & . & + & . & $\mathrm{x}$ & $\mathrm{x}$ \\
\hline Shipbuilding/repair & Asbestos & + & . & + & . & $x$ & $x$ \\
\hline Non-metallic mineral products & Silica & + & $* * *$ & + & $* * *$ & + & . \\
\hline General contractors & $\begin{array}{l}\text { Silica, asbestos, diesel } \\
\text { exhaust }\end{array}$ & + & $* * *$ & + & $* * *$ & Null & . \\
\hline Special-trade contractors & $\begin{array}{l}\text { Silica, asbestos, diesel } \\
\text { exhaust }\end{array}$ & + & $* * *$ & Null & . & + & * \\
\hline Transportation & Diesel exhaust & + & $* * *$ & + & $* * *$ & + & . \\
\hline Blacksmithing/welding shops & Welding fumes & + & * & + & . & $x$ & $x$ \\
\hline \multicolumn{8}{|l|}{ Occupation } \\
\hline Bartenders & $\begin{array}{l}\text { Environmental tobacco } \\
\text { smoke }\end{array}$ & ++ & $* * *$ & + & . & +++ & $* * *$ \\
\hline Waiters, hostesses, stewards & $\begin{array}{l}\text { Environmental tobacco } \\
\text { smoke }\end{array}$ & Null & * & - & * & Null & . \\
\hline Drilling/blasting & Silica & ++ & *** & ++ & $* * *$ & $\mathrm{x}$ & $\mathrm{x}$ \\
\hline Other mining/quarrying & Silica, asbestos, radon & ++ & $* * *$ & ++ & $* * *$ & +++ & $* * *$ \\
\hline Mineral ore treating & Silica, asbestos, radon & ++ & ** & + & * & $\mathrm{x}$ & $\mathrm{x}$ \\
\hline Metal smelting, converting, refining & Cadmium, arsenic, nickel & + & . & + & . & $x$ & $x$ \\
\hline Clay, glass, stone processing/forming & Silica & + & $* * *$ & + & ** & + & . \\
\hline Welding/flame cutting & Welding fumes & + & ** & + & . & + & . \\
\hline $\begin{array}{l}\text { Boilermakers, platers, structural metal } \\
\text { workers }\end{array}$ & Asbestos & ++ & $* * *$ & ++ & $* * *$ & $x$ & $x$ \\
\hline Painting/decorating & $\begin{array}{l}\text { Paint pigments, filaments, } \\
\text { resin }\end{array}$ & + & $* * *$ & + & . & +++ & $* * *$ \\
\hline Excavating/grading/paving & Silica & ++ & $* * *$ & ++ & $* * *$ & +++ & $* *$ \\
\hline Construction trades & $\begin{array}{l}\text { Silica, asbestos, diesel } \\
\text { exhaust }\end{array}$ & + & $* * *$ & + & $* *$ & ++ & $* * *$ \\
\hline Railway transport operating & Diesel exhaust & + & * & + & . & $x$ & $\mathrm{x}$ \\
\hline Bus drivers & Diesel exhaust & + & ** & + & * & + & * \\
\hline Truck drivers & Diesel exhaust & + & *** & + & $* * *$ & + & $* * *$ \\
\hline Stationary engine/utilities equipment & Diesel exhaust & + & *** & + & ** & $x$ & $x$ \\
\hline
\end{tabular}

Association scale based on HRs $---<0.50,--0.50-0.66,-0.67-0.94$, Null $0.95-1.04,+1.05-1.49,++1.50-1.99,+++>2.00$.

Probability scale based on $\mathrm{p}$ values. Not significant. ${ }^{*}<0.05,{ }^{* *}<0.01,{ }^{* * *}<0.0001$.

$x$, data not provided as they were under reporting threshold of $>5$ cases.

$\mathrm{PAH}$, polycyclic aromatic hydrocarbon.

workers, transportation workers, painters and bartenders-all of which have known exposures to Group 1 carcinogens as outlined by IARC.

Work related to mining, quarrying and construction has consistently shown increased risks due to workplace exposures to silica dust, asbestos, radon and diesel engine exhaust. ${ }^{20-22}$ Transport workers are also exposed to diesel engine exhaust and thus have shown increased risk of lung cancer in other studies in North America. ${ }^{89}$ The increased risk in painting occupations in ODSS and NOCCA can be attributed to their exposures to various hazardous chemicals in paint pigments, resins and filaments. ${ }^{23}$

Historically, employees working in bars and restaurants such as bartenders and waiters have shown increased risk of lung cancer partially due to exposures to secondhand smoking. ${ }^{17}$ Smoking in public settings such as bars was not banned in Ontario until $2006,{ }^{24}$ which may explain the elevated risk among bartenders (although only females reached significance) in ODSS. Increased risks were not observed in waiters and waitresses in ODSS, although it has been suggested that bartenders have a twofold to fourfold increase in secondhand smoke exposure compared with table waiting staff. ${ }^{25}$ Exposures to silica dust likely explain the significantly elevated risks in the other a priori groups, including iron foundries, non-metallic mineral products industries, clay/glass/stone processing and forming occupations and excavating/grading/paving positions. ${ }^{21} 23$ Finally, male boilermakers showed significantly increased risks in ODSS, which 
can be explained by their known occupational exposures to asbestos. $^{26}$

The results from this study add to the current understanding that workers in these fields are likely at higher risk of lung cancer due to occupational exposures. However, there were certain industries and occupations that did not show significantly elevated risks in ODSS despite having known exposures to IARC Group 1 carcinogens for lung cancer. Although construction workers overall had an excess risk of lung cancer, some specific roles (eg, brick and tile setting, concrete finishing, roofing) did not show increased risk. The discrepancy may be due to the possible low WSIB coverage in these construction occupations, as complete coverage across all construction industries has only recently become mandatory. ${ }^{27}$

In addition, higher risks were also expected in smelting occupations and industries due to metals such as copper, arsenic and nickel; welders due to the welding fumes that may comprise carcinogens such as nickel, chromium VI and cadmium; rubber products industries due to dust, fumes and chemicals from rubber production (which involve $\mathrm{N}$-nitrosamines and polycyclic aromatic hydrocarbons (PAHs)); iron/steel mills due to silica dust and shipbuilding industries due to asbestos. ${ }^{21}{ }^{28}$ While the results did not reach statistical significance, ODSS was able to identify trends in increased risk in these established high-risk groups.

Several groups with suspected work-related associations for lung cancer based on prior research were also observed to be at increased risk. For example, the potential exposures to metals, PAHs and asbestos among forging workers ${ }^{29}$ could likely explain the increased risk observed in ODSS. The increased risks in janitors may be due to asbestos exposure in the buildings of their workplace. Furthermore, motor vehicle assembly workers may be at elevated risk due to exposures to paint products and asbestos from brake installation. ${ }^{30}$ The increased risk among the defence services industry was more challenging to understand, as active military personnel are not part of the provincial workers' compensation plan used to create the cohort. While occupational associations for lung cancer are possible, exposures in defence services are diverse, and thus, it is difficult to identify the exact exposure agent(s) responsible. Lastly, while the results did not reach statistical significance, elevated risks were observed among workers in storage and printing industries, possibly due to exposures to diesel exhaust ${ }^{31}$ and chromium VI compounds, ${ }^{32}$ respectively. Future epidemiological studies could help ascertain whether the high risks in these groups may indeed be attributable to exposures to specific agent(s) at the workplace.

The overall division level results showed that generally, the highest risks were observed among blue-collar occupations (eg, mining, construction and transportation), as expected. The reduced risk among the agriculture industry has been well observed previously and is likely due to the lower rates of smoking among workers in this field. ${ }^{33}$ The reduced risks in occupations such as teaching and medicine/health may also reflect the effects of socioeconomic status on risk for lung cancer, ${ }^{35}$ as well as differences in smoking habits. However, discrepancies existed, such as the significantly elevated risks observed among the finance/insurance/real estate industries. Lastly, there were some differences between sexes in the results, where certain industries or occupations showed increased risk in males but not for females, and vice versa. In some cases, the number of female workers may have been too small to detect a difference for some groups. The possibility that males and females had different roles or exposures cannot be dismissed. ${ }^{36}$ These discrepancies demonstrate further avenues for investigating work-related risks.

\section{Limitations and strengths}

One limitation of the study was that only the industry and occupation specific to the time of the compensation claim was available, and employment at this time may not necessarily correspond to lifetime work history. While approximately one-third of the ODSS worker cohort had multiple claims, this was not sufficient data to reconstruct their full-work history. The dates or the duration of employment in a particular job could also not be determined. As a surveillance system, measurements of workplace exposures to potential carcinogens could not be obtained, which can vary between and within jobs and industries, as well as over time.

Information on smoking status, which may be more common among blue-collar workers, ${ }^{37}$ was also not available. However, it has been suggested that the absence of smoking data does not make a large difference in the risk estimates derived for associations between various occupation groups and lung cancer, particularly when there is a large and heterogeneous reference population. ${ }^{3839}$ Another limitation was that the WSIB covers 70 to 75 per cent of workers in Ontario. ${ }^{40}$ Thus, we were unable to capture relationships among non-covered industries such as trade unions, private day cares and travel agencies. Lastly, the analyses may have been susceptible to finding spurious associations between industries/occupations and lung cancer due to multiple testing. However, we applied a strict significance threshold of $99 \%$ to try to reduce these associations and primarily did not observe significantly elevated risks in industries and occupations without any plausible occupational risk for lung cancer.

A key strength of this study was the large sample of both male and female workers in Ontario. The occupational information was obtained before disease diagnosis, reducing information bias from data collection. Moreover, the authors believe that the occupational information on WSIB claims is collected carefully resulting in high data quality. Lastly, this surveillance system compared workers to workers, rather than workers to the general population, minimising the healthy worker effect and providing a comparison group that is more similar in social class and overall health.

\section{CONCLUSION}

This current study identified various high-risk occupation and industry groups for lung cancer in Ontario, supporting previous findings and demonstrating that ODSS can identify groups that are known to be at increased risk of occupational diseases such as lung cancer. The quantitative disease risk estimates obtained by this system can provide useful data to support the implementation of prevention programmes for lung cancer caused by workplace exposures. In the future, ODSS will be used to explore patterns of increased risk of other occupational diseases, including different cancers but also conditions such as silicosis, asthma, carpel tunnel syndrome and Raynaud's syndrome.

This work further demonstrates that the usage of workers' compensation claims, in conjunction with other administrative health databases, is a valid and feasible approach for occupational disease surveillance. Other jurisdictions with access to similar types of administrative health databases can look to implement similar approaches to conduct occupational disease surveillance.

Acknowledgements The authors would like to thank Nelson Chong for conducting the data linkage.

Contributors JKHJ drafted the manuscript, interpreted the findings and produced the figures/tables. SGF assisted in the manuscript writing and provided methodological expertise regarding the development of ODSS. JKHJ, LPL and JSM 
conducted the analyses. PAD, VHA, CBM and AP provided expertise in occupational health and administrative health data. PAD performed the selection of the a priori groups, conceived the study and provided overall supervision. All authors assisted in editing the manuscript.

Funding This project was funded by the Ministry of Labour (no 14-R-29) and the Public Health Agency of Canada (no 1516-HQ-000066). The Occupational Cancer Research Centre is supported from core funding from the Canadian Cancer Society and the Ontario Ministry of Labour.

Competing interests None declared.

Patient consent Not required.

Ethics approval Health Sciences Research Ethics Board, University of Toronto.

Provenance and peer review Not commissioned; externally peer reviewed.

(c) Article author(s) (or their employer(s) unless otherwise stated in the text of the article) 2018. All rights reserved. No commercial use is permitted unless otherwise expressly granted.

\section{REFERENCES}

1 Canadian Cancer Society, Statistics Canada, Public Health Agency of Canada. Canadian cancer statistics 2017. Ottawa: Canadian Cancer Society, 2017.

2 Rushton L, Hutchings SJ, Fortunato L, et al. Occupational cancer burden in Great Britain. Br J Cancer 2012;107(Suppl 1):S3-7.

3 Occupational and Environmental Working Group for the Toronto Cancer Prevention Coalition. Preventing occupational and environmental cancer: a strategy for Toronto. Toronto: City of Toronto, 2001.

4 Canadian Cancer Society, Statistics Canada, Public Health Agency of Canada. Canadian cancer statistics 2015. Ottawa: Canadian Cancer Society, 2015.

5 International Agency for Research on Cancer. Agents classified by the IARC monographs, volumes 1-118 2017. http://monographs.iarc.fr/ENG/Classification/ (accessed 29 May 2017).

6 Consonni D, De Matteis S, Pesatori AC, et al. Lung cancer risk among bricklayers in a pooled analysis of case-control studies. Int I Cancer 2015;136:360-71.

7 Taeger D, Pesch B, Kendzia B, et al. Lung cancer among coal miners, ore miners and quarrymen: smoking-adjusted risk estimates from the synergy pooled analysis of casecontrol studies. Scand J Work Environ Health 2015;41:467-77.

8 Garshick E, Laden F, Hart JE, et al. Lung cancer and vehicle exhaust in trucking industry workers. Environ Health Perspect 2008;116:1327-32.

9 Pintos J, Parent ME, Richardson L, et al. Occupational exposure to diesel engine emissions and risk of lung cancer: evidence from two case-control studies in Montreal, Canada. Occup Environ Med 2012:69:787-92.

10 Ramanakumar AV, Parent MÉ, Richardson L, et al. Exposures in painting-related occupations and risk of lung cancer among men: results from two case-control studies in Montreal. Occup Environ Med 2011;68:44-51.

11 Kendzia B, Behrens T, Jöckel KH, et al. Welding and lung cancer in a pooled analysis of case-control studies. Am J Epidemiol 2013;178:1513-25.

12 Pukkala E, Martinsen JI, Lynge E, et al. Occupation and cancer - follow-up of 15 million people in five Nordic countries. Acta Oncol 2009:48:646-790.

13 Dubrow R, Sestito JP, Lalich NR, et al. Death certificate-based occupational mortality surveillance in the United States. Am J Ind Med 1987;11:329-42.

14 Koehoorn M, Tamburic L, McLeod CB, et al. Population-based surveillance of asthma among workers in British Columbia, Canada. Chronic Dis Inj Can 2013;33:88-94.

15 Cherry N, Beach J, Burstyn I, et al. Data linkage to estimate the extent and distribution of occupational disease: new onset adult asthma in Alberta, Canada. Am J Ind Med 2009:52:831-40.

16 World Health Organization. Environmental and occupational cancers 2011. http:// www.who.int/mediacentre/factsheets/fs350/en/ (accessed 19 June 2017).

17 Jensen JA, Schillo BA, Moilanen MM, et al. Tobacco smoke exposure in nonsmoking hospitality workers before and after a state smoking ban. Cancer Epidemiol Biomarkers Prev 2010;19:1016-21.
18 Cancer Care Ontario. Ontario Cancer Registry 2015. https://www.cancercare.on.ca/ ocs/csurv/ocr/ (accessed 19 May 2017).

19 World Health Organization. Classification of Diseases (ICD) 2016. http://www.who. int/classifications/icd/en/ (accessed 19 May 2017).

20 Driscoll T, Nelson DI, Steenland K, et al. The global burden of disease due to occupational carcinogens. Am J Ind Med 2005:48:419-31.

21 International Agency for Research on Cancer. IARC monographs on the evaluation of the carcinogenic risks of chemicals to humans: Arsenic, metals, fibres, and dusts. Volume 100C. Lyon: IARC; 2012. http://monographs.iarc.fr/ENG/Monographs/ vol100C/index.php.

22 International Agency for Research on Cancer. IARC monographs on the evaluation of the carcinogenic risks of chemicals to humans: Radiation. 2012. Lyon: IARC. Volume 100D. http://monographs.iarc.fr/ENG/Monographs/vol100D/.

23 International Agency for Research on Cancer. IARC monographs on the evaluation of the carcinogenic risks of chemicals to humans: Chemical agents and related occupations. Volume 100F. Lyon: IARC; 2012. http://monographs.iarc.fr/ENG/ Monographs/vol100F/index.php.

24 Government of Ontario. Smoke-free Ontario 2014. https://www.ontario.ca/page/ smoke-free-ontario (accessed 28 June 2017).

25 Maskarinec MP, Jenkins RA, Counts RW, et al. Determination of exposure to environmental tobacco smoke in restaurant and tavern workers in one US city. J Expo Anal Environ Epidemiol 2000;10:36-49.

26 O'Reilly KM, Mclaughlin AM, Beckett WS, et al. Asbestos-related lung disease. Am Fam Physician 2007;75:683-8.

27 The Workplace Safety and Insurance Board. FAQ - Mandatory coverage in construction 2017. http://www.wsib.on.ca/WSIBPortal/faces/WSIBDetailPage? cGUID=WSIB013886\&rDef=WSIB_RD_ARTICLE\&_afrLoop $=1363692685201000$ \& afrWindowMode=0\& afrWindowld=null\#\%40\%3FcGUID\%3DWSIB013886\%26 afrWindowld\%3Dnull\%26_afrLoop\%3D1363692685201000\%26rDef\%3DWSIB_ RD_ARTICLE\%26_afrWindowMode\%3D0\%26_adf.ctrl-state\%3D4xdyuj5uu_29 (accessed 16 Oct 2017)

28 Guha N, Loomis D, Guyton KZ, et al. Carcinogenicity of welding, molybdenum trioxide, and indium tin oxide. Lancet Oncol 2017;18:581-2.

29 Moulin JJ, Clavel T, Roy D, et al. Risk of lung cancer in workers producing stainless steel and metallic alloys. Int Arch Occup Environ Health 2000;73:171-80.

30 Cole DC. Cancer in the auto industry: A map of the literature for the Industrial Disease Standards Panel 1994. http://www.canoshweb.org/odp/html/rp2.htm (accessed 19 Jul 2017).

31 CAREX Canada. Lung carcinogens: occupational exposure summary package 2014. http://www.occupationalcancer.ca/wp-content/uploads/2014/07/CAREX-CanadaLung-carcinogens.pdf (accessed 25 July 2017)

32 Centers for Disease Control and Prevention. Criteria for a recommended standard: Occupational exposure to hexavalent chromium Atlanta: CDC, 2013.

33 Alavanja MC, Sandler DP, Lynch CF, et al. Cancer incidence in the agricultural health study. Scand J Work Environ Health 2005;31(Suppl 1):39-45. discussion 5-7.

34 Blair A, Zahm SH, Pearce NE, et al. Clues to cancer etiology from studies of farmers. Scand J Work Environ Health 1992;18:209-15.

35 Ekberg-Aronsson M, Nilsson PM, Nilsson JA, et al. Socio-economic status and lung cancer risk including histologic subtyping--a longitudinal study. Lung Cancer 2006:51:21-9.

36 Kennedy SM, Koehoorn M. Exposure assessment in epidemiology: does gender matter? Am J Ind Med 2003:44:576-83.

37 Gaudette LA, Richardson A, Huang S. Which workers smoke? Health Rep 1998; 10:35-45

38 Axelson 0. Aspects of confounding and effect modification in the assessment of occupational cancer risk. J Toxicol Environ Health 1980;6:1127-31.

39 Blair A, Steenland K, Shy C, et al. Control of smoking in occupational epidemiologic studies: methods and needs. Am J Ind Med 1988;13:1-4.

40 Association of Workers' Compensation Boards of Canada. Canadian workers' compensation system - Year at a glance 2017. http://awcbc.org/?page_id=11803 (accessed 16 Oct 2017) 